\title{
Educational Experience in the Mobile Learning Environment: Consumer Behaviour Perspective
}

\author{
https://doi.org/10.3991/ijim.v14i21.18441 \\ Galina Volkovitckaia $\left({ }^{\bowtie}\right)$ \\ Herzen State Pedagogical University of Russia, \\ Saint Petersburg, Russian Federation \\ volkovitckaiaga@rambler.ru /galialap@mail.ru \\ Yuliya Tikhonova \\ Sechenov First Moscow State Medical University, \\ Moscow, Russian Federation \\ Olga Kolosova \\ State University of Management, Moscow, Russian Federation
}

\begin{abstract}
The development of digital technologies necessitates the formation of digital literacy and entrepreneurship skills in the modern "digital generation". The study has as the objective to identify the aspects of consumer demand for educational services in the process of testing the conceptual model of mobile learning adapted to the modern business environment in the context of digital transformations of the socio-economic life. The concept of an educational course based on the Sakai mobile learning platform with a focus on the formation of digital literacy in the business segment has been proposed in the study. The educational and applied course "Entrepreneurship in the Digital Mode" was tested within the educational programs of the State University of Management (Lyubertsy, Russia) and Herzen State Pedagogical University of Russia (St. Petersburg, Russia). The experiment made it possible to identify key aspects of consumer demand for distance education based on the characteristics of the participants' perception of the advantages and effectiveness of mobile learning. Most participants confirmed their professional achievements and the fact of the implementation of personal educational goals. Mobile learning was described as an easy, comfortable, interesting, innovative and modern method of learning compared to traditional classroom lessons. In the process of mobile learning, students demonstrated an increase in personal responsibility and self-organization while practical classes and the synergy of the educational content with real business cases greatly contributed to their involvement and productivity. Until now, research has not dealt with real measurable in terms of real income from specific activities, the results of the application of mobile learning. The contribution of this study to the area under study is to establish pedagogical demands that can be satisfied with mobile learning.
\end{abstract}

Keywords - Digital economy, entrepreneurship, mobile learning, mobile learning platforms 


\section{Introduction}

Over the past decades, mobile computing has become incredibly popular due to the use of the Internet, e-mail, multimedia technologies and intelligent learning systems [1]. Mobile technologies provide users with unlimited access to information and resource tools [2]. The capabilities of the online environment are changing the perception of time and space of communication and providing access to information resources and exchange at any time and in any place based on parallel access paths. Mobile technologies have become intermediaries in the learning process that provide new methods of accessing and using educational materials and define the mobile learning model [3].

Mobile learning is a new phenomenon in the educational context which is being rapidly spread [4]. Mobile applications for educational purposes have provided users with the opportunity to easily interact with information anywhere and anytime. Due to the fact that mobile technology has come into common use, it has become an essential teacher and student tool providing educational benefits [5]. Student and teacher communication and interaction has been changed by the introduction of communication tools that allow the simultaneous and distributed exchange of ideas and online collaboration [1].

The format simplicity, accessibility and convenience attract consumers of educational products. The widespread use of technology, constantly updated information, people's need for access to information and personalized learning have contributed to the emergence of distance learning, e-learning and mobile learning [6]. Mobile learning (m-learning) is developed based on e-learning and mobility [7] and is an interesting and effective tool for improving the quality of education [8]. Research and practical mobile learning projects have been actively developing since the early $90 \mathrm{~s}$ in a wide range of areas based on the use of various technologies and a wide range of communication devices [9]. The modern "digital generation" of students define mobile learning as the use of tablets, personal computers or smartphones to acquire knowledge and useful skills [10], which allows them to more easily exchange information, facilitates receiving and solving educational tasks and helps to establish good collaboration in the group [11]. Mobile learning improves learning competence through its convenience and speed as students always have access to their mobile phones [12]. Mobile applications are integrated with Wi-Fi, 4G and 5G telecommunications networks, which are based on wireless technologies; this allows students to access educational resources, including lectures, assignments, and quizzes, as well as to collaborate and receive support regardless of their location and time [13]. Mobile learning also allows students apply specialized mobile cloud platforms for collaboration, information exchange and selfeducation [14].

In mobile learning, a virtual mobile learning platform is a classroom where the student, as the centre of the learning environment, interacts with the educational institution, curriculum and the teacher through mobile devices and the Internet [15]. Mobile applications provide access to e-learning content regardless of student location and support the implementation of educational goals online. Mobile learning consists of M-LMS (mobile learning management system); M-content (mobile learning); 
MCMS (mobile content management system); M-testing (assessment of learning outcomes); M-students (a group of users studying lessons in the system [16]. The factors of the mobile learning program implementation include access and impetus, response, interactions, learning activities, learning sources, and assessment [17]. In the systemic constructivism of a mobile learning system, spheres and factors are synchronized and combined; this creates organizational and managerial levers of influence on students and ensures the effectiveness of the educational cycle.

The inclusion of mobile approaches in the educational cycle is considered from the perspective of the effectiveness and efficiency of achieving educational goals; the competitiveness of educational structures and their innovative ability to provide highquality education; user-friendliness of the educational content. The main feature of modern mobile learning is integration with existing Massive Open Online Courses (MOOC) through access to cloud services through publicly available mobile technologies [18]. One of the most important issue of educational research is enhancing academic performance through mobile learning [6]. A number of approaches have been used to examine the potential impact of mobile learning on student involvement, motivation, critical thinking and knowledge acquisition [9]. Distance education research confirms the benefits of mobile learning to the learning environment, which is evidenced by the analysis of the use of mobile devices in teaching practice. For example, mobile technologies support student motivation, encourage their responsibility [19], increase commitment [20], contribute to learning and retention [21]. They also develop organizational skills and the ability to self-regulate; maintain communication between educational process participants through real-time data exchange [22]; improve students' thinking skills and self-confidence; support independent, constructivist and contextual learning by offering active and experiential learning opportunities [9]. These studies are based primarily on surveys or research on objective test results of students, but not on the practical impact of implementing mobile learning in solving real life problems. User-friendliness and flexibility are the key advantages of mobile learning; the benefits of integrating mobile learning exceed the functional limitations of mobile devices, in particular in relation to the possibility of personal feedback, which has a positive impact on the learning achievements [23].

In the concept of mobile learning, education is considered as a social process of acquiring knowledge and skills through interaction and cooperation. Social interaction is a motivational and attractive asset in the educational cycle; student involvement in educational social networks, microblogs and virtual discussions develops the ability to establish connections between thoughts, synchronize theoretical and practical knowledge, as well as to expand the boundaries of cognition [24]. In addition, a multimedia application not only improves cognition, reduces learning anxiety and increases motivation, but also provides sufficient visual and auditory support. Another value of mobile devices and learning is enhanced educational collaboration and the integration of real business problems [9] into the educational environment, which can ensure the applied nature of the educational program in real-time. Mobile learning naturally displaces passive learning, increases intellectual [25] and emotional participation in learning activities [1]. 
Mobile learning offers exciting possibilities for enhancing collective learning by providing personalization of learning and orientates it to the needs of the individual student. However, this learning methodology is still not used with full capabilities in the curriculum. It should be noted that new technologies, offering a range of alternatives, are rapidly changing the format of mobile learning and makes control over its use unlikely. A modern learning system mobile basis should appreciate the personal and technical aspects of learning, as well as technologies and aspects related to their development and interoperability [26].

The global reach of mobile devices and applications has shaped new business models and supply processes in the business segment which are characterized by virtualization, informatization and digitalization. The development of digital technologies necessitates the formation of digital literacy and entrepreneurship skills in the modern "digital generation". The use of mobile technologies in teaching is natural for them, but the question of the effectiveness of its application is not removed. The problem to be explored in this paper is how exactly the representatives of this generation assess the training services they need in terms of the results of the practical application of knowledge, especially in such a practically oriented area as entrepreneurship.

Thus, the purpose of the study is to identify the aspects of consumer demand for educational services in the process of testing the conceptual model of mobile learning adapted to the modern business environment in the context of digital transformations of the socio-economic life. The following research tasks have been set:

- To develop the concept of an educational course based on the Sakai mobile learning platform with a focus on the formation of digital literacy in the business segment.

- To form an experimental group based on certain criteria.

- To test the educational and applied course "Entrepreneurship in the Digital Mode" in the framework of the educational programs of the State University of Management (Lyubertsy, Moscow region, Russia) and Herzen State Pedagogical University of Russia (St. Petersburg, Russia).

- To monitor the educational process and identify the key levers of influence on the involvement and productivity of participants.

- To identify and describe the features of the participants' perception of the advantages and effectiveness of mobile learning.

\section{$2 \quad$ Methods}

In the digital era, mobile learning is becoming a component of higher education. The study of disciplines based on mobile applications is gaining popularity, and technological solutions are auxiliary elements that ensure a high-quality and competitive educational process.

The experiment involved testing of the educational and applied course "Entrepreneurship in the Digital Mode" designed to be further implemented in the program of regional cooperation and personnel development.

The experiment was carried out from September 2019 to April 2020 in the framework of the educational programs of the State University of Management (Lyubertsy, 
Moscow region, Russia) and Herzen State Pedagogical University (St. Petersburg, Russia).

The study involved 362 graduate students. The age of the respondents ranged between 23 and 30 years old (Table 1).

Table 1. Sample (university students)

\begin{tabular}{|l|l|c|c|l|}
\hline \multicolumn{1}{|c|}{ University } & \multicolumn{1}{|c|}{ Postgraduate program } & $\begin{array}{l}\text { Number of } \\
\text { participants }\end{array}$ & Age & Gender \\
\hline $\begin{array}{l}\text { State University of Management } \\
\text { (Lyubertsy, Russia) }\end{array}$ & $\begin{array}{l}\text { Management of innovative business } \\
\text { development }\end{array}$ & 217 & $24-30$ & $\begin{array}{l}\text { Male-140, } \\
\text { Female-77 }\end{array}$ \\
\hline $\begin{array}{l}\text { Herzen State Pedagogical } \\
\text { University of Russia }\end{array}$ & $\begin{array}{l}\text { Psychological counselling: profes- } \\
\text { sional activities and interpersonal } \\
\text { interaction }\end{array}$ & 145 & $23-27$ & $\begin{array}{l}\text { Male-49, } \\
\text { Female-96 }\end{array}$ \\
\hline
\end{tabular}

The experimental group was formed based on the following criteria:

- Availability of one's own business project ready for implementation and commercialization.

- The average cost of a unit of goods or services in the monetary range from 10 to 75 US dollars.

- Readiness to legalize entrepreneurial activity in accordance with the legislation of the Russian Federation.

- Readiness to constantly interact throughout the course duration - presence in the online environment.

- Readiness to conduct business activities after completing the course.

Participation in the study was completely voluntary. Before the start, the participants were familiar with the direction and meaning of the study and its conditions, and only those who volunteered to participate and met the criteria for the initial selection described above participated. Thereafter, the participants underwent sequential training using the following experimental pedagogical products according to three stages.

No personal data of the participants was collected or used in the research process.

The structure of the experimental educational product involved 3 stages of the educational activity (Fig. 1).

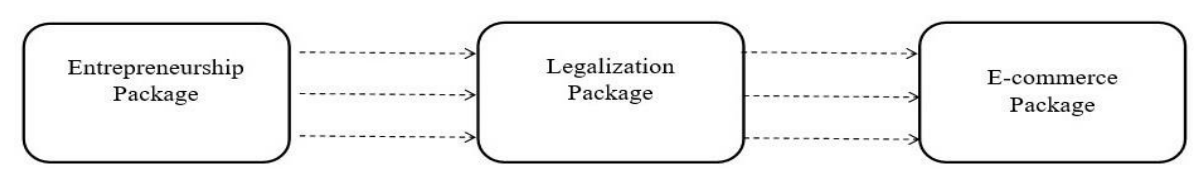

Fig. 1. The experiment structures

* Own development 
The "Entrepreneurship" package ( 3 months) focused on the acquisition of theoretical and applied knowledge and skills related to the organization and management of business processes and the development of entrepreneurial activities. The course took place remotely on the Sakai mobile learning platform. The package also included a mobile coaching program called "Leader", which provided psychological and motivational support in the educational process.

The "Legalization" package (1 month) provided information on the procedures to legalize the entrepreneurial activity and considered legal aspects of doing business in the Russian Federation.

The E-commerce package ( 3 months) provided support to promote goods and services in the e-commerce system. Trade in goods and services was carried out between the course participants.

In order to measure, the study used indicators of the commercial success of participants who implemented the knowledge gained in the course of their own business activities. To maintain anonymity, the participants used unique identification numbers, randomly generated during their participation in the experiment. The collection of information about their commercial success was carried out using signed invoices, information on payments received for the goods and services provided in electronic payment systems, notarial certificates on concluded contracts and other types of commercial and accounting documents provided by the participants in the experiment under their identification number.

To achieve the objectives of the study, it is important to evaluate the practical side of learning and the results achieved, measured by profit. Assessment of various aspects of training needs using the conceptual model of mobile learning adapted to the modern business environment was carried out based on the level of commercial success of the participants.

\section{$3 \quad$ Results and Discussion}

Digital economy has transformed the traditional types of economic activity and the style of socio-economic interaction of business entities and shaped completely new business models based on digital technologies: Cloud technologies, artificial intelligence, virtual reality, Big Data. Technology platforms as the basis of digital economy business models are involved in almost all economic processes and perform various functions related to the achievement of the more effective use of resources in the production and sale of products and ensuring the marketing activities of business units.

The concept of digitalization of business processes has three key advantages that are relevant for any type of business: infrastructure efficiency increase, the emergence of new business models, revenue increase or cost reduction through the introduction of digital platforms in marketing and sales activities.

The development of the digital concept of doing business necessitates transformation of the traditional approaches to acquiring knowledge and skills in the business segment with a focus on mobility, virtuality and contact. 
The concept of digital economy develops and disseminates the concept of digital education, which has become a trendy learning style in corporate and university structures.

The development of digital technologies necessitates the formation of digital literacy and entrepreneurship skills in the modern "digital generation". Entrepreneurship education based on mobile devices conceptually meets the challenges of digital transformation and relies on the analysis of modern demands for education in the digital reality. This enhanced the development of an educational course based on the Sakai mobile learning platform with a focus on the formation of digital literacy in the business segment.

The Sakai learning platform is an open-source software that is free licensed and used for teaching, research, and collaboration. The Sakai software is based on Java technologies, is well structured, and includes a number of major and auxiliary modules [27].

When completing educational package 1included in the "Entrepreneurship in the Digital Mode" course based on the Sakai learning platform, students demonstrated a high level of readiness for mobile learning and ease of interaction with the technological aspects of distance education. Eighty-seven percent of students found mobile learning comfortable and user-friendly.

In order to ensure high student involvement and activity rates, the "Entrepreneurship" Package was supplemented with coaching support given as constant online consultations and communication with mentors (Herzen State Pedagogical University teachers). The attitude of students to coaching support turned out to be positive; $93 \%$ of students confirmed the constructive influence of the Leader program on their personal productivity in the process of achieving educational goals. From the organizational perspective, the coaching program that complemented the course allowed the moderators to keep control over the presence of students in the online environment, coordinate interactions in the educational group, and manage the dynamics of the complex academic progress. Herzen State Pedagogical University students reported that the "Leader" program encouraged them to develop professional activities related to psychological counselling; this was confirmed by $75 \%$ of students. Coaching support encouraged $73 \%$ of State University of Management students to acquire professional knowledge and skills; it also contributed to self-management and interaction coordination.

The concept of the "Entrepreneurship" package in the "Entrepreneurship in the Digital Mode" course based on the Sakai learning platform is described in Fig. 2. 
Sakai mobile learning platform

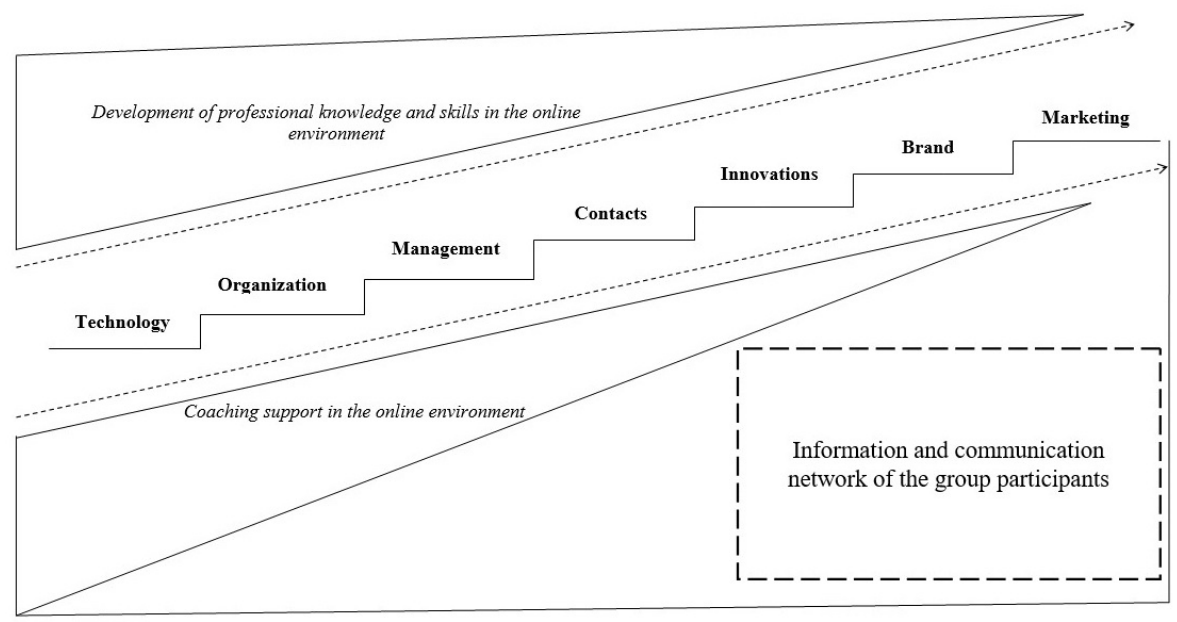

Fig. 2. The concept of the "Entrepreneurship" package in the "Entrepreneurship in the

Digital Mode" course based on the Sakai learning platform

* Own development

The research participant selection criteria included the consent to legalize entrepreneurial activity in accordance with the legislation of the Russian Federation; thus, the registration of business entities was carried out at the second stage of the "Legalization" program.

At the third stage of completing the "Entrepreneurship in the Digital Mode" course, $93 \%$ of participants showed high rates of activity, involvement and presence in the online environment.

As for the implementation of business ideas in the digital environment, State University of Management students actively commercialized commodity products while Herzen State Pedagogical University students were engaged in the implementation of services related to psychological counselling, mentoring and coaching, which was influenced by the master's degree programs (Table 2). This confirms the practicality and effectiveness of the course as an auxiliary program aimed at the implementation of the ultimate goals of master's degree programs, the applied nature of education, and the promotion of employment. 
Table 2. Commercial offers made by the online educational process participants in the "E-commerce" environment

\begin{tabular}{|l|c|c|c|}
\hline Commercial offers in the E-commerce Package & Participants & $\begin{array}{c}\text { Number of trade } \\
\text { operations }\end{array}$ & $\begin{array}{c}\text { Turnover } \\
\text { (US dollars) }\end{array}$ \\
\hline Goods & 222 & 1652 & 46112 \\
\hline Clothes & 32 & 256 & 5888 \\
\hline Homeware & 27 & 162 & 6642 \\
\hline Office supplies & 10 & 60 & 720 \\
\hline Children products & 19 & 133 & 6251 \\
\hline Haberdashery & 16 & 80 & 1840 \\
\hline Beauty products & 29 & 261 & 2871 \\
\hline Books & 4 & 24 & 240 \\
\hline Audio, video, photos & 17 & 102 & 1428 \\
\hline Telephony and mobile communications & 36 & 324 & 16200 \\
\hline Gardening & 13 & 117 & 1638 \\
\hline Sport and hobbies & 19 & 133 & 2394 \\
\hline Services & 140 & 1057 & 15786 \\
\hline Psychological counselling & 55 & 495 & 5940 \\
\hline Website promotion and copywriting & 12 & 96 & 1056 \\
\hline Education & 50 & 300 & 3900 \\
\hline Tourism & 5 & 40 & 3000 \\
\hline Health and beauty & 18 & 126 & 1890 \\
\hline
\end{tabular}

* Own development

The experiment allowed us to identify the characteristics of the participants' perception of the advantages and effectiveness of mobile learning, namely:

- Most participants confirmed their professional achievements when completing the course $(87 \%)$.

- $93 \%$ of students confirmed the fact of the implementation of personal educational goals.

- $75 \%$ of students described mobile learning as a comfortable, easy and exciting method of learning compared to traditional classroom classes.

- $93 \%$ of students found the course innovative and modern.

- $94 \%$ of students reported an increase in personal responsibility and self-organization.

- $87 \%$ of students noted that practical activities and the synergy of the educational content with real business cases encouraged them to participate in the learning process and contributed to their productivity.

- The course inspired $87 \%$ of students to start their professional activities.

- $80 \%$ of students stated their willingness to take additional and subsequent business courses related to their professional activities.

Socio-economic and technical changes along with the information society and digital economy needs have determined the trends towards the introduction of software, computer and information technologies, reduction of printed papers, digitization of almost all spheres of the socio-economic life. This requires that the educational content should be updated in the new conditions of digital technological opportunities [28]. The 
exponential growth of technology has determined the primary goal of higher education institutions, which is to improve learning outcomes and academic performance by integrating students with mobile learning [13].

The transformation of education towards digital openness and information accessibility forces educational institutions to invest funds and intellectual resources in e-learning in order to increase competitive advantages, ensure modern and high-quality educational experience and professional effectiveness of students. The most optimal method for implementing mobile learning is to use it from elementary school and even preschool period $[29,30]$. The formation of appropriate thinking skills and the use of electronic technology to solve learning problems forms optimal skills not only for further training, but also for professional activity in adulthood [31]. Despite the fact that children are constantly using electronic devices, these devices are not a real learning environment. Without special motivation and without creating a learning situation, they can even harm the formation of a person's cognitive abilities. This circumstance becomes the reason for the ambiguous attitude of parents towards the use of electronic devices in teaching a child. Parental involvement is critical to the correct use of electronic device techniques in the early stages of learning [32]. A critical factor in the effective use of mobile and mobile-based online learning is technology acceptance and appreciation by educators. The training of teachers in early school and for the preschool period makes it possible to transform the digital environment into a learning environment that is natural for a child and then a student and an adult developing in a situation of a total digital environment [33,34].

The purpose of various technologies that are used in education is to facilitate the effective achievement of learning goals and enrich educational content through modern technological capabilities. The most integral modern form of distant learning is online learning platforms like Moodle [15]. Given the fact that wireless technologies provide access to information regardless of physical location and time, mobile devices can constructively influence the learning process. Mobile devices make it possible to make integration into existing training platforms and services the most natural, and the implementation of any training course the fastest and most inexpensive [18].

From the perspective of the commercialization of an educational product, innovative technological solutions and mobile applications allow reaching a significant audience through mobile devices, which does not require a lot of investment [35]. This allows you to expand the possibilities of commercial use of mobile and online networks and establish communication with the user and the customer in the most suitable way for him, as shown by the results of our research, where the use of one or another software product was not conditioned.

The perceived quality of information that a commercial proposal is based on should be considered as the major factor to forecast consumer behaviour when making decisions on taking an educational course. Thus, the quality of the information provided has a significant impact on the quality of the group course. The perceived usefulness, quality of information, and attitude are significant metrics that predict the behaviour of consumers of educational services. In addition, the quality of the mobile learning system, which is determined by user-friendliness, ease of access, and reliability, provides 
a potential student with an additional educational benefit, which in turn affects involvement, trust in the producer of the educational content and stimulates the purchase of an educational package. Mobile learning at the level of learning platforms needs user friendliness in order to attract and adapt students to mobile learning [26].

Given the growing demand of the modern digital generation for mobile learning educational institutions should adjust their learning environment, educational programs, and teaching to the needs of modern consumers, changing learning styles and new learning technologies [6]. However, mobile learning should help students and educators by providing services that facilitate entire educational process rather than replace traditional learning style $[25,35]$. To some extent, the problem is that previous studies did not use real practical benefits and results in the practical activities of graduates as a form of objective assessment of the use of elements of mobility and online learning in the course. Thus, there is currently no basis for comparing such results with our study.

The most successful educational practices are those that implement mobile technologies as a teaching aid in a blended learning environment. Mobile technologies can be successfully integrated into the learning process provided there are appropriate learning methods; the proper use of technology in the learning environment allows the student to acquire lifelong learning skills [9]. Educational content producers should first develop an effective plan of course and identify technologies for the course support. Mobile orientation of the educational course is not determined by the use of certain devices; it should be a good tool to ensure its effectiveness [36].

From the point of view of the quality educational process, the implementation of mobile learning should consider three aspects of mobility: Student mobility, learning mobility and technology mobility. Students should be given control over the course content or material as they will be using the application to study remotely. Learning mobility is the adjustment of the educational material to the mobile technology characteristics. Technology mobility involves the use and adjustment of all mobile features to the learning design. In general, the goal is to make the learning paradigm maximally integrated to the digital learning environment [4].

\section{Conclusion}

The development of digital technologies necessitates the formation of digital literacy and entrepreneurship skills in the modern "digital generation". Entrepreneurship education based on mobile devices conceptually meets the challenges of digital transformation and relies on the analysis of modern demands for education in the digital reality. This enhanced the development of an educational course based on the Sakai mobile learning platform with a focus on the formation of digital literacy in the business segment.

The experiment made it possible to identify key aspects of consumer demand for distance education based on the characteristics of the participants' perception of the advantages and effectiveness of mobile learning. Most participants confirmed their professional achievements and the fact of the implementation of personal educational goals. Mobile learning was described as an easy, comfortable, interesting, innovative, 
and modern method of learning compared to traditional classroom lessons. In the process of mobile learning, students demonstrated an increase in personal responsibility and self-organization while practical classes and the synergy of the educational content with real business cases greatly contributed to their involvement and productivity. Most participants stated their willingness to take additional and subsequent business courses related to their professional activities.

For the first time, the article examines the results of the use of pedagogical techniques based on real results and measurable incomes of research participants. The results allow us to determine the effectiveness and benefits of mobile learning based on real results of using knowledge to solve problems in business. In the future, research should be aimed at determining the relevant factors that affect the needs of students and their practical results and determining the correlations between them to increase the effectiveness of the use of pedagogical programs.

\subsection{Research limitations}

The experiment was carried out within the framework of the educational process of graduate students undergoing formal training in higher educational institutions. In order to introduce the educational product into the regional interaction and entrepreneurial activity development strategy aimed at the youth of the Russian Federation, the target audience should be expanded by business representatives operating in priority areas and an educational program should be offered to the mass consumer. This will outline consumer demand in the business segment and adapt the developed concept of the business course to specific areas of the economic activity of business entities.

\section{$5 \quad$ References}

[1] Talib, C.A., Aliyu, H., Malik, A.M, Siang, K.H., Novopashenny, I., Ali, M. (2019). Sakai: A Mobile Learning Platform. International Journal of Interactive Mobile Technologies, 13(11): 95-110. https://doi.org/10.3991/ijim.v13i11.10800

[2] Papadakis, S., Kalogiannakis, M. (2017). Mobile educational applications for children: what educators and parents need to know. International Journal of Mobile Learning and Organisation, 11(3):256-277. https://doi.org/10.1504/ijmlo.2017.085338

[3] Blilat, A., Ibriz, A. (2020). Design and Implementation of P2P Based Mobile App for Collaborative Learning in Higher Education. International Journal of Interactive Mobile Technologies, 14(7): 115-132. https://doi.org/10.3991/ijim.v14i07.13167

[4] Hamzah, A., Hidayatullah, A.F., Persada, A.G. (2020). Discovering Trends of Mobile Learning Research Using Topic Modelling Approach. International Journal of Interactive Mobile Technologies, 14(9): 4-14. https://doi.org/10.3991/ijim.v14i09.11069

[5] Sadovnikova N.O., Mirzaahmedov A.M. (2019). Relevant Concepts of a Teacher's State When Experiencing Professional Identity Crisis. The Education and science journal, 21(2): 113-131. (In Russian). https://doi.org/10.17853/1994-5639-2019-2-113-131

[6] Talan, T. (2020). The effect of mobile learning on learning performance: A meta-analysis study. Educational Sciences: Theory and Practice, 20(1): 79-103. https://doi.org/10.12738/ jestp.2020.1.006 
[7] Noor, T.H., Zeadally, S., Alfazi, A., Sheng, Q.Z. (2018). Mobile cloud computing: Challenges and future research directions. Journal of Network and Computer Applications, 115: 70-85. https://doi.org/10.1016/j.jnca.2018.04.018

[8] Al-Arabiat, D., Ahmad, W.F.W., Sarlan, A. (2016). Cloud computing role to address mobile learning barriers: An exploratory study of HEIs in Malaysia. In 2016 3rd International Conference on Computer and Information Sciences (ICCOINS). IEEE. pp. 553-558. https://doi.org/10 $.1109 /$ iccoins.2016.7783275

[9] Marzouki, O.F., Idrisi, M.K., Bennani, S. (2017). Effects of social constructivist mobile learning environments on knowledge acquisition: A meta-analysis. International Journal of Interactive Mobile Technologies, 11(1): 18-39. https://doi.org/10.3991/ijim.v11i1.5982

[10] Darmaji, D., Kurniawan, D.A., Astalini, A., Lumbantoruan, A., Samosir, S.C. (2019). Mobile Learning in Higher Education for the Industrial Revolution 4.0: Perception and Response of Physics Practicum. International Journal of Interactive Mobile Technologies, 13(9): 4-20. https://doi.org/10.3991/ijim.v13i09.10948

[11] Baharom, M.M., Atan, N.A., Rosli, M.S., Yusof, S., Hamid, M.Z.A. (2020). Integration of Science learning Apps based on Inquiry Based Science Education (IBSE) in enhancing Students Science Process Skills (SPS). International Journal of Interactive Mobile Technologies, 14(9): 95-109. https://doi.org/10.3991/ijim.v14i09.11706

[12] Al-Harrasi, H., Al-Khanjari, Z. Sarrab, M. (2015). Proposing a new design approach for Mlearning applications. International Journal of Software Engineering and its Application, 9(11): $11-24$.

[13] Kopnov, V.A., Shmurygina, O.V., Shchipanova, D.E., Dremina, M.A., Papaloizou, L., Orphanidou, Y., Morevs, P. (2018). Functional Analysis and Functional Maps of Qualifications in Ecvet Context. The Education and science journal, 20(6): 90-117. https://doi.org/10.17853 1994-5639-2018-6-90-117

[14] Khaddage, F., Müller, W., Flintoff, K. (2016). Advancing mobile learning in formal and informal settings via mobile app technology: Where to from here, and how? Educational Technology and Society, 19(3): 16-26.

[15] Papadakis, S., Kalogiannakis, M., Sifaki, E., Vidakis, N. (2018). Evaluating Moodle use via Smart Mobile Phones. A case study in a Greek University. EAI Endorsed Transactions on Creative Technologies, 5(16): 1-9. https://doi.org/10.4108/eai.10-4-2018.156382

[16] Khlaisang, J. (2018). Ubiquitous Technology Enhanced Learning: The Outcome-Based Learning Design for 21st Century Learners. Educational Invention and Innovation Research Unit, Faculty of Education, Chulalongkorn University, Bangkok.

[17] Mueangpud, A., Khlaisang, J., Koraneekij, P. (2019). Mobile Learning Application Design to Promote Youth Financial Management Competency in Thailand. International Journal of Interactive Mobile Technologies, 13(12): 19-38. https://doi.org/10.3991/ijim.v13i12.11367

[18] Papadakis, S., Kalogiannakis, M., Sifaki, E., Vidakis, N. (2017). Access Moodle using smart mobile phones. A case study in a Greek University. In Interactivity, Game Creation, Design, Learning, and Innovation. Springer, Cham, pp. 376-385. https://doi.org/10.1007/978-3-31976908-0 36

[19] Khasanova, I.I., Kotova, S.S. (2018). Psychological Readiness of Secondary Vocational Education Teachers for Mastering New Activities in the Context of Professional Reorientation. The Education and science journal, 20(7): 147-167. https://doi.org/10.17853/1994-5639-2018-7147-167

[20] Brooks, D.C., Pomerantz, J. (2017). ECAR Study of Undergraduate Students and Information Technology, 2017. EDUCAUSE.

[21] Zhang, L., Nouri, J. (2018). A Systematic Review of Learning and Teaching with Tablets. In 14th International Conference of Mobile Learning, pp. 1-10.

[22] Kuprina, T.V., Beketova, A.P., Minasyan, S.M. (2019). Self-Organizing Systems in the Context of Academic Environment. The Education and science journal, 21(1): 150-169. https://doi.org/10.17853/1994-5639-2019-1-150-169 
[23] Hanafi, Y., Murtadho, N., Ikhsan, M.A., Diyana, T.N. (2020). Reinforcing Public University Student's Worship Education by Developing and Implementing Mobile-Learning Management System in the ADDIE Instructional Design Model. International Journal of Interactive Mobile Technologies, 14(2): 215-241. https://doi.org/10.3991/ijim.v14i02.11380

[24] Stanojevic, L., Rakic, B. (2018). Mobile technology in higher education-a student perspective on learning with mobile computing devices. In Successful Implementation of Information Technology: It, Marketing, Education and Business Working Together for Business Success. Silver and Smith Publishers, London, pp. 8-27.

[25] Park, S.Y., Lee, H.D., Kim, S.Y. (2016). South Korean university students' mobile learning acceptance and experience based on the perceived attributes, system quality and resistance. Innovations in Education and Teaching International, 55(4): 450-458. https://doi.org/10.1080/ 14703297.2016.1261041

[26] Zidoun, Y., Dehbi, R., Talea, M., Arroum, F.-Z.A. (2019). Designing a Theoretical Integration Framework for Mobile Learning. International Journal of Interactive Mobile Technologies, 13(12): 152-170. https://doi.org/10.3991/ijim.v13i12.10841

[27] Sakai. Introducing Sakai. Retrieved from https://www.sakaiproject.org/

[28] Galstyan, O.V., Smetannikov, A.P., Kolbaya, I.G., Palchikova, G.S., Galigorov, D.V., Mazkina, O.B. (2020). Application of Mobile Technologies for the Formation of Analytical Competence of Future Specialists. International Journal of Interactive Mobile Technologies, 14(2): 242-249. https://doi.org/10.3991/ijim.v14i02.11658

[29] Papadakis, S., Vaiopoulou, J., Kalogiannakis, M., Stamovlasis, D. (2020). Developing and Exploring an Evaluation Tool for Educational Apps (ETEA) Targeting Kindergarten Children. Sustainability, 12(10): 4201. https://doi.org/10.3390/su12104201

[30] Kalogiannakis, M., Papadakis, S. (2017). Pre-service kindergarten teacher's acceptance of "Scratch. Jr" as a tool for learning and teaching computational thinking and Science education. In Proceedings of the $12^{\text {th }}$ Conference of the European Science Education Research Association (ESERA), Research, practice and collaboration in science education, pp. 21-25.

[31] Dorouka, P., Papadakis, S., Kalogiannakis, M. (2020). Tablets and apps for promoting robotics, mathematics, STEM education and literacy in early childhood education. International Journal of Mobile Learning and Organisation, 14(2): 255-274. https://doi.org/10.1504/ijmlo.2020.100 26334

[32] Papadakis, S., Zaranis, N., Kalogiannakis, M. (2019). Parental involvement and attitudes towards young Greek children's mobile usage. International Journal of Child-Computer Interaction, 22: 100144. https://doi.org/10.1016/j.ijcci.2019.100144

[33] Papadakis, S. (2018). Evaluating pre-service teachers' acceptance of mobile devices with regards to their age and gender: a case study in Greece. International Journal of Mobile Learning and Organisation, 12(4): 336-352. https://doi.org/10.1504/ijmlo.2018.10013372

[34] Kalogiannakis, M., Papadakis, S. (2019). Evaluating pre-service kindergarten teachers' intention to adopt and use tablets into teaching practice for natural sciences. International Journal of MobileLearningandOrganisation,13(1):113-127.https://doi.org/10.1504/ijmlo.2019.10016617

[35] Alshurideh, M.T., Salloum, S.A., Kurdi, B.A., Monem, A.A., Shaalan, K. (2019). Understanding the Quality Determinants that Influence the Intention to Use the Mobile Learning Platforms: A Practical Study. International Journal of Interactive Mobile Technologies, 13(11): 157-183. https://doi.org/10.3991/ijim.v13i11.10300

[36] Dodd, L. (2017). Implementing classroom instruction that works. TLN Journal, 24(3): 10. 


\section{Authors}

Volkovitckaia Galina Andreevna is a $\mathrm{PhD}$, Associate Professor of the Department of Education Management and Personnel Management, Herzen State Pedagogical University of Russia, Saint Petersburg, Russian Federation. Email: mailto:volkovitckaiaga@,rambler.ru / mailto:galialap@mail.ru

Tikhonova Yuliya Anatolievna is a Candidate of Pharmaceutical Sciences, Associate Professor of the Department of organization and economics of pharmacy, Sechenov First Moscow State Medical University, Moscow, Russian Federation. Email: mailto:Kafedra-oef2012@yandex.ru

Kolosova Olga Anatolievna is a $\mathrm{PhD}$, Associate Professor of the Department of Sociology and Psychology of Management, State University of Management, Moscow, Russian Federation. Email: oa_kolosova@guu.ru

Article submitted 2020-09-11. Resubmitted 2020-10-18. Final acceptance 2020-10-18. Final version published as submitted by the authors. 